torpedo in communication with an electric battery, by means of a metallic wire which connects it with the port, and so cause an explosion.

\section{THE CONTINUITY OF THE PROTOPLASM IN PLANT TISSUE}

THE translation of Dr. Schaarschmidt's paper in a recent number of NATURE (January 29th, I 885 ) gave those who, like myself, are unable to read Hungarian, full details both of his researches and views, and as one much interested in the subject of "the continuity of the protoplasm," I should like to be allowcd to make a few remarks upon it.

To refer first of all to a matter of minor importance with reference to sieve-tubes, I see that Dr. Schaarschmidt says: "The first direct observation was made in 1854 by Hartig, and not by Sachs, as Walter Gardiner states." This refers to the opening passage of my paper in the Arbeiten des Botanischen Instituts in Würzburg, Band III., Heft I., where I say : "A most important addition was made to our knowledge of the histology of tissues in I 863 by Sachs, and in the following year by Hanstein, when they demonstrated that in the sieve-tubes first described by Hartig there are perforations in the transverse walls, \&c." I made that statement, relying, as I still do, on the authority of Prof. Sachs's text-book (English edition, I882, p. 89), since it scemed to me that Hartig's observation, which could not be confirmed by "Mohl and others," was actually proved and demonstrated beyond doubt by Sachs and Hanstein, and, moreover, in fresh and not in macerated tissue.

With respect to the main subject under immediate consideration, I shall first make one or two general statements as to the continuity of the protoplasm in plant tissues. In my paper in the Würzburg Arbeiten, to which $I$ have already referred, I have spoken of two appearances of continuity: one which I speak of as direct, and the other as indirect. By direct or unbroken continuity, I mean the appearance of a thick protoplasmic process, extending between, and uniting the protoplasmic contents of two contiguous cells: the pits forming one continuous canal, and being uninterrupted by a pit-closing membrane. In this case, therefore, the idea of open pits is necessitated. By indirect continuity I mean the existence of a pit-closing membrane between the two opposite protoplasmic processes in the pits: the membrane being perforated in a sicve-like manner, and thus allowing the two protoplasmic processes to become united to one another by means of delicate protoplasmic filaments which traversc the pit-closing membrane. I further stated that my observations led me to believe that a pit-closing membrane was present in all cases, and that the appearance of a direct unbroken continuity is fallacious. (See also Roy. Soc. Proc., December I 3 th, I 883 .)

Turning now to the consideration of the observations made upon the Florideae, I shall have to differ somewhat with Dr. Schaarschmidt; but, while I do so, I wish it to be quite clearly understood that I do not in the least undervalue the work of those investigators to whom I refer, and who, according to my view, have not actually demonstrated a continuity of the protoplasm from cell to cell, but have only observed facts which render the existence of such a continuity extremely probable. Thus, since I regard the perforation of the pit-closing membrane as proving continuity, I hold that the observations of Bornet, Perceval Wright, and Agardh (I have unfortunately not seen KolderupRosenvinge's paper) have not demonstrated continuity, but have demonstrated that the pit-protoplasm clings with remarkable tenacity to the pit-closing membrane. Hick has simply repeated the observations of these investigators, and of his results the same may be said. Since, therefore, Schmitz ( 1883 ) has found that a pit-closing membrane does cxist ; that it is perforated in a sieve-like manner, and that therefore the continuity is not direct, but indirect, it seems to me that to him alone belongs the credit of having demonstrated the continuity of the protoplasm in the Florideae, and I have myself (Proc. Camb. Phil. Soc., February I Ith, 1884) been able to confirm his results as to the existence of the closing membrane in question.

In considering the history of the subject, and leaving sieve-tubes out of the question, it is clear that Tangl's observation (1880) on the endosperm cells of Phoenix and Sirychnos was the first new discovery in the direction of the continuity of the protoplasm between neighbouring cells. Then came Strasburger's classic work on the cellwall ("Bau und Wachsthum der Zellhäute," I 882) ; his observations on the porosity of the pit-closing membranes, and his valuable suggestions as to the probability of cellwall perforation, together with the citation of instances which already occurred, and his cxtremely interesting observation with regard to the swarm-spores of Vaucheria. Naturally Volvox, Pandorina, and the zoospores of Hematococcus offer other examples of the perforation of the cell-membranc by protoplasm.

After Strasburger came Russow. Russow read his first paper at the January meeting of the Dorpat Society Sitzber. d. Dorpater Nat. Gesell., I882), but it did not come into my hands until some time after I had published my first observation (Quart. Jour. Mic. Sci., October, I882), so that, at least from that point of view, my work was quite independent and original. As to the order of the other papers, I agree with Dr. Schaarschmidt, except that I would like to add to his list the papers of Pfurtscheller (Selbstverlag des k. k. Franz Foseph Gymnasiums, I 883), Will, (Bot. Zeit., 52, I 884), Tangl (Sitzb. derk. Akad. der Wiss., Bd. 90, 1884), and Goroschankin (Bot. Zeit., 4I, I883).

As to Dr. Schaarschmidt's claiming, in I 884 , the suggestion of the universality of the occurrence of continuity of the protoplasm in plant-cells, I think that, considicring the state of the subject at that time (April, I883) something may also be said in my favour, for I find in my Royal Society paper (Phil. Trans. Roy. Soc., April, 1883) the following statement:- "Although I am aware of the danger of rushing to conclusions, I cannot but remark that when these results (which were foreshadowed by Sachs and Hanstein, when they discovered the perforation of the sieve-plate) are taken in connection with those of Russow, it appears extremely probable that not only in the parenchymatous cells of pulvini, in phloem parenchyma, in endosperm cells, and in prosenchymatous bast fibres, is continuity established from cell to cell, but that the phenomenon is one of much wider, if not of universal, occurrence." 1

Passing on to the results of Dr. Schaarschmidt's second paper, to which he refers, where he gives a very long list of tissues in which he has demonstrated the existence of a continuity of the protoplasm, I should only wish to remark that while he appears to have observed in a satisfactory manner, and with comparative ease, cases that have appeared to me to be excessively difficult, yet his figures of such continuity are not satisfactory, and in many of them it is the direct and not the indirect continuity which his drawings represent. As I have stated clsewhere $(A r b$. $d$. Bot. Inst. Witrzburg) an examination of fresh unswollen tissue with iodine and chlor. zinc. iod. will always demonstratc the presence of a pit-closing membrane.

I now come to it subject which I approach with some regret, since, in dealing with it, I have to dissent from the expressed opinions of a number of competent observers, and especially do I feel this regret with regard to one of those papers-viz. that by one of the most distinguished

${ }^{1} \mathrm{Mr}$. Dycr has already very kindly alluded to this subject on my behalf. hurry of publication I had not referred to Hartig's paper (February 18, 1885). 
investigators of plant histology: Prof. Russow. The subject is that of the existence of intercellular protoplasm.

Dr. Schaarschmidt has already given the literature. The only other observation with which I am acquainted is that of Prof. Frommann ("Zur Lehre von der Bildung der Membran von Pflanzenzellen"-separate pamphlet) who finds in the intercellular spaces of the young stem of Ricinus communis, protoplasm ; starch grains, and chlorophyll grains.

The observations as to the existence of intercellular protoplasm depend chiefly upon the staining reactions of iodine and sulphuric acid or chlor. zinc. iod. The cell wall turns blue, or remains yellow as the case may be : the protoplasm, and in certain cases a substance; in or lining the intercellular spaces, stains dark brown. Or again in some instances-e.g., the rhizome of Aspidium filix masthe substance in the intercellular space remains uncoloured. Other observers have employed other staining reagents after swelling with sulphuric acid and chlor. zinc. iod.-e.g., saffranin, eosin, or anilin blue - and in this case a colouration is observed of the protoplasm on the one hand and of the intercellular space substance on the other.

Dealing first with the iodine and sulphuric acid or chlor. zinc. iod. method, it is obvious that, besides the protoplasm which assume; the well-known dark brown colouration, any lignified, cuticularised or suberised membranes would react in the same way, and in the case of one of Berthold's (Ber. d. Deut. Bot. Gesell.) examples, e.g., young stem of Ligustrum vulgare, the substance which so markedly stains, does actually consist of the external membrane of the intercellular space, which towards the free surface has undergone changes associated with partial lignification (Gardiner, Proc. Camb. Phil. Soc., Nov. Ioth, 1884), as can be readily proved by treating a section with aniline chloride and hydrochloric acid, when the well-known gold yellow reaction of lignified tissue appears. In the same way the substance which does not stain with iodine and sulphuric acid might be of a mucilaginous nature, and like the mucilage of the external portions of the wall of the seed of Ceratonia siliqua give the same reaction, viz., remain uncoloured. But there are cases which are not so easy to deal with, as I have stated elsewhere (Proc. Camb. Phil. Soc., Feb. I Ith, I884), I found that the Hofmann's blue which I had so successfully employed for demonstrating the existence of protoplasmic filaments in the pit-closing-membrane stained not only protoplasm but also certain forms of mucilage. Like Russow (Sitzber. $d$. Dorpat. Naturfor., Sept., 1883), I thought at first that in Aucuba Japonica I had discovered the existence of intercellular protoplasm, but I observed later on that this staining substance could be seen to arise as drops on the external walls and that these drops went blue with iodine : thus demonstrating that they were not protoplasm but mucilage. I therefore made experiments with the methylene blue which I had found (Phil. Trans., part iii., I883) to be so useful as a stain for the cell wall, and so differentiating in its action. (A solution is made in water containing a trace of alcohol ; the solution being diluted with water before use. The section freed from alcohol by repeated washing, is left to stain for about 20 seconds, washed and mounted in water). I further found that methylene blue stains equally well, all substances formed by the degeneration of cellulose walls, such as mucilage and the like. So while Hofmann's blue stains protoplasm and mucilage, but not cell wall, methylene blue stains cellwall and mucilage but not protoplasm. Thus the cell-wall and protoplasm may be readily discriminated in a very satisfactory manner, and without this reaction it would indeed be hard to distinguish the two. Many dyes behave like Hofmann's blue so far as the staining of the mucilage is concerned, and I have little doubt but that eosin resembles it in this respect, though not such a good differentiating stain for the protoplasm. In the course of all my experiments, which I have repeated several times,
I have never found intercellular protoplasm but often intercellular mucilage. In all cortex tissues which are often remarkable for their mucilaginous character -e.g., Viscum, Fraxinus, Ilex-mucilaginous degeneration of the free cell-walls very usually occurs, which often-e.g., Ilex, Viscum-extends even to the whole middle lamella. In Aspidium filix-mas, Blechnum Braziliense and other ferns, theso-called cuticularised threads (cuticularfädèn) are in reality rods consisting mainly of mucilage which arise as drops on the free surface of the cell-wall and increase in length by repeated basipetal formation. I do not therefore find nyself able to allow of the existence of intercellular protoplasm.

As to the middle lamella being protoplasm I can only refer to the statements $I$ made with regard to Frommann and Elsberg's researches (Quart. Jour. Mic. Sci., March, I883) and I share fully in the opinion of Prof. Russow ("Ueber die Auskleidung der Intercellularen," Sitzber. d. Dorpat. Naturfor., August, I 884) that if such were the case it is clear that we could have no such thing as a mass of tissue resisting great stress. The cells cannot be connected together by protoplasm. As to the existence of the intercellular chlorophyll grains of which Dr. Schaarschmidt speaks, and the chlorophyll grains and starch grains observed by Prof. Frommann, I also share Prof. Russow's view (loc. cit.) that the above investigators must have been deceived by some abnormal appearance, for what could be the physiological significance of such a phenomenon? The full details of my researches on the subject will, I hope, shortly appear in the Quarterly Journal of Microscopical Science.

WALTER GARDINER

Botanical Laboratory, Cambridge, February Io

\section{THE BANGOR LABORATORIES}

$\mathrm{THE}$ following is a description of the Laboratories of Univerrsity College, Bangor, which were opened by Sir William Thomson on the 2 nd inst. The illustration shows the ground floor arrangement; in the upper floor are a magnetism-room and an optical gallery.

The new physical and chemical laboratories occupy the site of the old stables and coach-houses of the "Penrhyn Arms Hotel," which is now used as the main building of the College; and, to lessen expense, a plan has been adopted by which the old walls are, as far as possible, taken advantage of for outside walls and partitions. To utilise the available space to the utmost it was decided to roof in the whole area, which measures about $\mathrm{I} 20$ feet by 80 feet. This area is bounded on the east by the main building of the College; on the south by a private road which runs nearly parallel to the Shrewsbury and Holyhead turnpike road, and gradually ascends until opposite the laboratories, the ground is about 20 feet above the level of the turnpike; on the west and north by the private grounds of the College.

At the extreme east end of the south front of the laboratory buildings is a wide door opening into a vestibulc, from which a passage leads north, and terminates in a wider space or hall. From this hall a long corridor runs parallel to the south front, dividing the floor space into two nearly equal parts. Of these the southern is set apart for physics, the northern for chemistry.

The physical and chemical lecture-theatres $(23,4 \mathrm{I})$ are of the same size, 32 feet square and 19 fcet high, and are placed side by side with the corridor as a separating space between them. The internal arrangements are nearly the same in both rooms. The students' entrances are opposite one another in the corridor. The benches, eight in number, rise from the front to the back of the room, and front toward the west. The lecture-tables arc placed about 4 feet from the front bench, and between each table and the west wall there is a clear space between 7 and 8 feet wide. In the physical lecture-theatre the table is supported on four pillars of masonry, and is en- 